УДК 544.344.016.2:543.573:543.442.2:662. 662.641

\title{
ВИВЧЕННЯ ТЕРМІЧНИХ ВЛАСТИВОСТЕЙ ТВЕРДОГО ЗАЛИШКУ ТОРФУ ПІСЛЯ ЕКСТРАГУВАННЯ ГУМУСОВИХ РЕЧОВИН
}

\author{
Михайлик В.А. ${ }^{1}$, канд. техн. наук, Снсжкін Ю.Ф. ${ }^{1}$, член-кореспондент НАН України, \\ Оранська О.І. ${ }^{2}$, канд. хім. наук, Корінчевська Т.В. ${ }^{1}$, Корінчук Д.М. ${ }^{1}$, канд. техн. наук \\ ${ }^{1}$ Институт технической теплофизики НАН Украины, ул. Желябова, 2а, Киев, 03680, Украина \\ ${ }^{2}$ Інститут хімії поверхні ім. О.О. Чуйка НАН України, вул. Генерала Наумова 17, Київ, 03164, \\ Украӥна
}

\begin{tabular}{|c|c|}
\hline Представлені & Представлены \\
\hline дослідження & исследования \\
\hline дериватографії та рентгенофазово- & рентгенофазового \\
\hline го аналізу термічних властивостей & анализа термических свойств твер- \\
\hline твердого залишку фрезерного тор- & дого остатка фрезерного торфа по- \\
\hline фу після екстрагування гумусових & экстрагирования гумусовых \\
\hline речовин 3 метою визначення його & веществ с целью определения соот- \\
\hline відповідності вимогам до палив. По- & ветствия его требованиям, предъяв- \\
\hline казано, що температурні інтервали & ляемым к топливам. Показано, что \\
\hline термічного розкладання органічних & температурные интервалы терми- \\
\hline речовин залишку значно ширші & ческого разложения органических \\
\hline за такі чистого торфу, а їх величи- & веществ остатка значительно более \\
\hline на прямо залежить від температу- & широкие, чем торфа, а их величи- \\
\hline екстракції. Встановлено, що в & ны прямо зависят от температуры \\
\hline тасті високих & экстракции. У \\
\hline стю оксидів кальцію та кремнію, а & гемператур при уча- \\
\hline також іонів натрію в залишку & стии оксидов кальция и кремния, а \\
\hline ворюються нові тверді ф & также ионов натрия в остатк \\
\hline нано порівняння теплових & разовываются новые твердые фазы. \\
\hline термічного розкладання органічних & Выполнено сравнения тепловых \\
\hline речовин торфу та залишку. Запропо- & эффектов термического \\
\hline новано спосіб використання ТЗТ як & ния органических веществ торфа и \\
\hline палива. & $\begin{array}{l}\text { остатка. Предложен способ исполь- } \\
\text { зования остатка как топлива. }\end{array}$ \\
\hline
\end{tabular}

In this study the thermal gravimetric and differential thermal analysis (TGA\&DTA) and X-ray diffraction used to evaluate the thermal properties of solid residues of milled peat after extraction of humus substances to determine its compliance with the requirements for fuels. It was shown that the temperature ranges of thermal decomposition of organic substances in the residue considerably wider than those of the peat, and their values are directly depend on the extraction temperature. It was found that new solid phases in residues appeared at high temperature in the presence of calcium and silicic oxides and sodium ions. Also the thermal effects during the thermal decomposition of organic matter and peat residue were compared. The method of use residues as fuel was proposed.

Бібл. 14, табл. 1, рис. 8.

Ключові слова: дериватографія, рентгенофазовий аналіз, торф, гумусові речовини, термічне розкладання.

I - інтенсивність відбиття;

$\theta$-кут падіння-відбиття пучка рентгенівського випромінювання.

\section{Скорочення:}

ГР - гумусові речовини;

\section{Bcmyn}

Енергетика України переживає не кращі свої часи. Обмаль коштів в державі, високі ціни на природний газ, мазут та інші викопні види палива змушують інтенсифікувати розвиток виробництва альтернативних видів палива та відновлювати
ДТА - диференціальний термічний аналіз; ДТГ - диференціальна термогравіметрія; РФА - рентгенофазовий аналіз; T - температура; ТГ - термогравіметрія; ТЗТ - твердий залишок торфу після екстракції.

видобуток торфу. Проте крім енергетичного використання торф широко застосовується як добриво і може бути сировиною для виробництва фізіологічно активних речовин на основі гумусових речовин (ГР), що входять до його складу, для використання в рослинництві, садівництві, 
тваринництві та виробництві кормів [1-4]. В умовах гострої необхідності в збільшенні продуктивності сільського господарства нагальним стає питання комплексного використання торфу на торфобрикетних заводах. Ідея полягає в тому, щоб певну частину торфу, що видобувається для енергетичних потреб, використовувати для виробництва екстракту ГР, а твердий залишок торфу (ТЗТ) після екстрагування ГР, направляти для виробництва палива в технологічній лінії торфобрикетного заводу. Використання ТЗТ в якості палива вимагає дослідження його властивостей з метою визначення відповідності його вимогам до палив.

\section{Матеріали та методи}

Матеріали. В дослідженні було використано фрезерний торф низинного типу 3 родовища Ірванцевського торфобрикетного заводу (Чернігівська обл., м. Семенівка), тверді залишки фрезерного торфу після екстрагування гумусових речовин та золи ТЗТ. Екстракцію здійснювали в пульсаційному диспергаторі ударного типу [5] після обробки торфу розчином гідроксиду натрію 3 розрахунку $10 \% \mathrm{NaOH}$ на суху масу торфу. Температуру та час екстрагування змінювали в межах $20 \ldots 100^{\circ} \mathrm{C}$ та $40 \ldots 60$ хв.

Методи. Термічні дослідження проводили в дериватографі Q-1000 системи Paulik-PaulikErdey (фірма «МОМ», Угорщина) [6] в діапазоні 20...1000 ${ }^{\circ} \mathrm{C}$ при швидкості нагрівання 7,4 K/хв. Зразки розміщували в відкритий конічний керамічний тигель без стискання, шаром, висотою $10 \ldots 11$ мм. Атмосферою слугувало нерухоме повітря. В якості інертної речовини в тиглі порівняння використовували оксид алюмінію. Корекцію шкали температур здійснювали по температурі переходу кварцу $3 \alpha$ - в $\beta$-форму $\left(573{ }^{\circ} \mathrm{C}\right)$ [7]. Відхилення температури не перевищувало \pm 1 К. Збір та обробка інформації 3 дериватографа здійснювались за допомогою прикладної комп'ютерної програми «Derivatograph», створеної в середовищі програмування Delphi [8].

Дериватографічний метод, що об'єднує термогравіметрію (ТГ) з класичним диференціальним термічним аналізом (ДТА), знайшов широке застосування в наукових дослідженнях та виробничих лабораторіях [9-11]. Він дозволяс отримати інформацію про поведінку індивідуальних речовин i ïx сполук в умовах програмованого нагріву. Якісна та кількісна оцінка процесів, що відбуваються при нагріванні зразків, здійснюється за кривими зміни температури зразка (Т), його маси (ТГ), диференціальної термогравіметрії (ДТГ), що являє собою похідну від кривої ТГ, та ДТА. Крива ДТА представляє різницю температур між зразком та інертним матеріалом, дає можливість ідентифікувати теплові процеси, що відбуваються в зразку при його нагріванні. У зв'язку з наявним термічним опором матеріалу зразка та стінок керамічного тигля температура максимумів піків теплових ефектів (ДТА) вища за температуру відповідних максимумів швидкості зміни маси (ДТГ).

Рентгенофазовий аналіз (РФА) твердого залишку після екстрагування гумусових речовин 3 торфу та золи після нагрівання твердого залишку до $1000{ }^{\circ} \mathrm{C}$ виконували на дифрактометрі ДРОН-4-07 у відфільтрованому нікелем $\mathrm{Cu} \mathrm{K}_{\alpha}$ випромінюванні аноду та геометрії зйомки по Бреггу-Брентано [12].

\section{Результати досліджень та аналіз одержсаних даних}

Дериватограма на рисунку 1 відображає процеси, що відбуваються у фрезерному торфі при його нагріванні. Якщо провести умовну пряму лінію між початком відхилення кривої ДТА від горизонтальної прямої, яка є підтвердженням теплової рівноваги в системі в ізотермічному режимі $\left(20^{\circ} \mathrm{C}\right)$, до перетину 3 кривою в точці при $781{ }^{\circ} \mathrm{C}$, що відповідає завершенню всіх термічних процесів, одержимо найбільш вірогідну передбачувану базову лінію дериватографа, щодо кривої ДТА [13]. Відхилення кривої ДТА нижче базової лінії вказує на наявність ендотермічних процесів, вгору - на екзотермічні. Виходячи 3 цього бачимо, що до $202^{\circ} \mathrm{C}$ реєструється ендотермічний процес зневоднення торфу, після завершення якого розпочинається виділення теплоти пов'язане 3 термічним розкладанням органічних речовин, яке завершується при $688^{\circ} \mathrm{C}$. В інтервалі $688 \ldots 781^{\circ} \mathrm{C}$ спостерігаємо ендотермічний процес термічної дисоціації карбонатів.

Вподовж відмічених інтервалів температур маса зразка зменшується. Виходячи з ходу кривої (ДТГ), швидкість зменшення маси зразка в процесі термічної деградації органічних речовин змінюється в два етапи, що обмежені інтервалами 202...393 та 393...688 ${ }^{\circ} \mathrm{C}$. На рисунку схематично показана ме- 
тодика визначення температурних інтервалів зміни маси зразка, використовуючи криві ТГ та ДТГ. На першому етапі розкладається 46,31 \% органіки 3 середньою швидкістю $0,023 \%$. середня швидкість розкладання зменшується до $0,015 \% / c$. В результаті видалення $\mathrm{CO}_{2}$ при термічній дисоціації карбонатів, зменшення маси зразка складає 2,2 мг (або 1,68 \% на суху масу). Результати визначення вологості, вмісту органічних речовин, карбонату кальцію та зольності торфу представлено в таблиці.

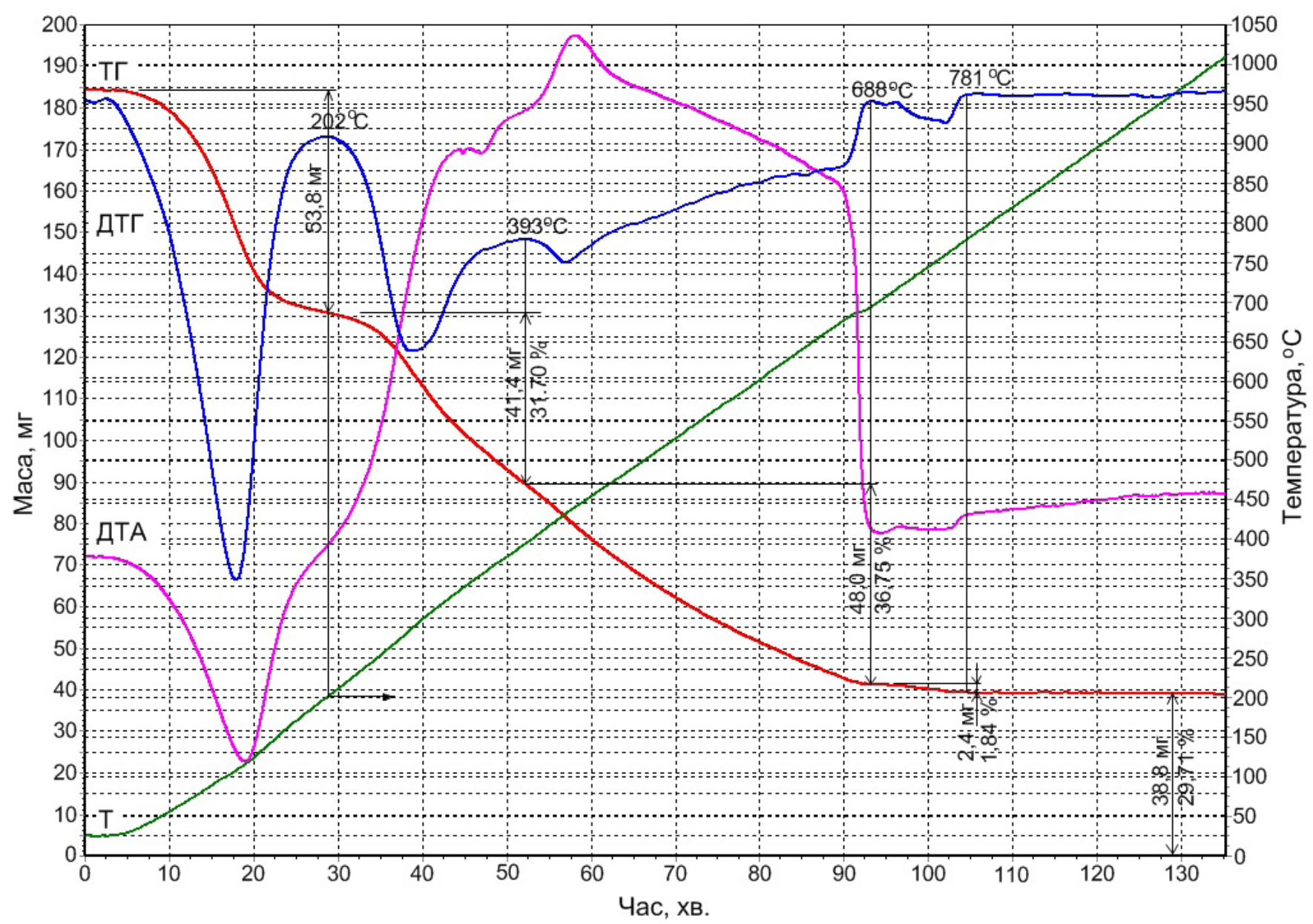

Рис. 1. Дериватограма фрезерного торфу. Маса зразка 184,4 м2.

Дериватографічні дослідження зразків ТЗТ, одержаних при різних температурах екстракції ГР, показали, що обробка торфу розчином $\mathrm{NaOH}$ призводить не тільки до утворення розчинних у воді гуматів (солей гумінових кислот), а і до якісних змін в органічних речовинах, що залишаються в ТЗТ (рис. 2 та 3). Термічне розкладання органічних речовин ТЗТ на відміну від органіки чистого торфу відбувається в більш широкому температурному інтервалі і проходить в три етапи. Так в ТЗТ, одержаного після екстракції ГР при $100{ }^{\circ} \mathrm{C}$ протягом 60 хв. (рис. 2), перший етап спостерігається в інтервалі $204 \ldots 358{ }^{\circ} \mathrm{C}$, другий $-358 . .599$ і третій
- 599...931 ${ }^{\circ} \mathrm{C}$. Середня швидкість розкладання на цих етапах, відповідно складає 0,019, 0,011 та 0,012 \%/c. Максимальної швидкості розкладання набуває при 293, 444 та $821^{\circ} \mathrm{C}$. Порівнюючи бачимо, що швидкість термічного розкладання органічних речовин торфу перевищує швидкість розкладання органічних речовин ТЗТ.

Зольність ТЗТ значно менша за зольність вихідного торфу (таблиця). Очевидно в результаті декантації частина мінеральних речовин в вигляді кварцового піску та залишків раковин молюсків видаляється 3 торфу, що і відображається на зольності ТЗТ. Проте вміст 
золи в ТЗТ з підвищенням температури екстракції зростає, що пов'язане з більш глибокими процесами взаємодії лугу з компонентами торфу.

Збільшення температури взаємодії лугу з компонентами торфу в процесі екстракції ГР призводить до розширення температурного діапазону розкладання органічних речовин ТЗТ в високотемпературну область. Етапи термічного розкладання стають біль вираженими (рис. 3). Зниження швидкостей розкладання та розширення температурного діапазону свідчать про зміни, що відбуваються в якісному складі торфу при його обробці лугом. Ймовірно в результаті взаємодії лугу з органічними компонентами торфу одночасно утворюються як розчинні сполуки ГР з іоном $\mathrm{Na}+$, так і не розчинні, що мають більшу термічну стійкість.

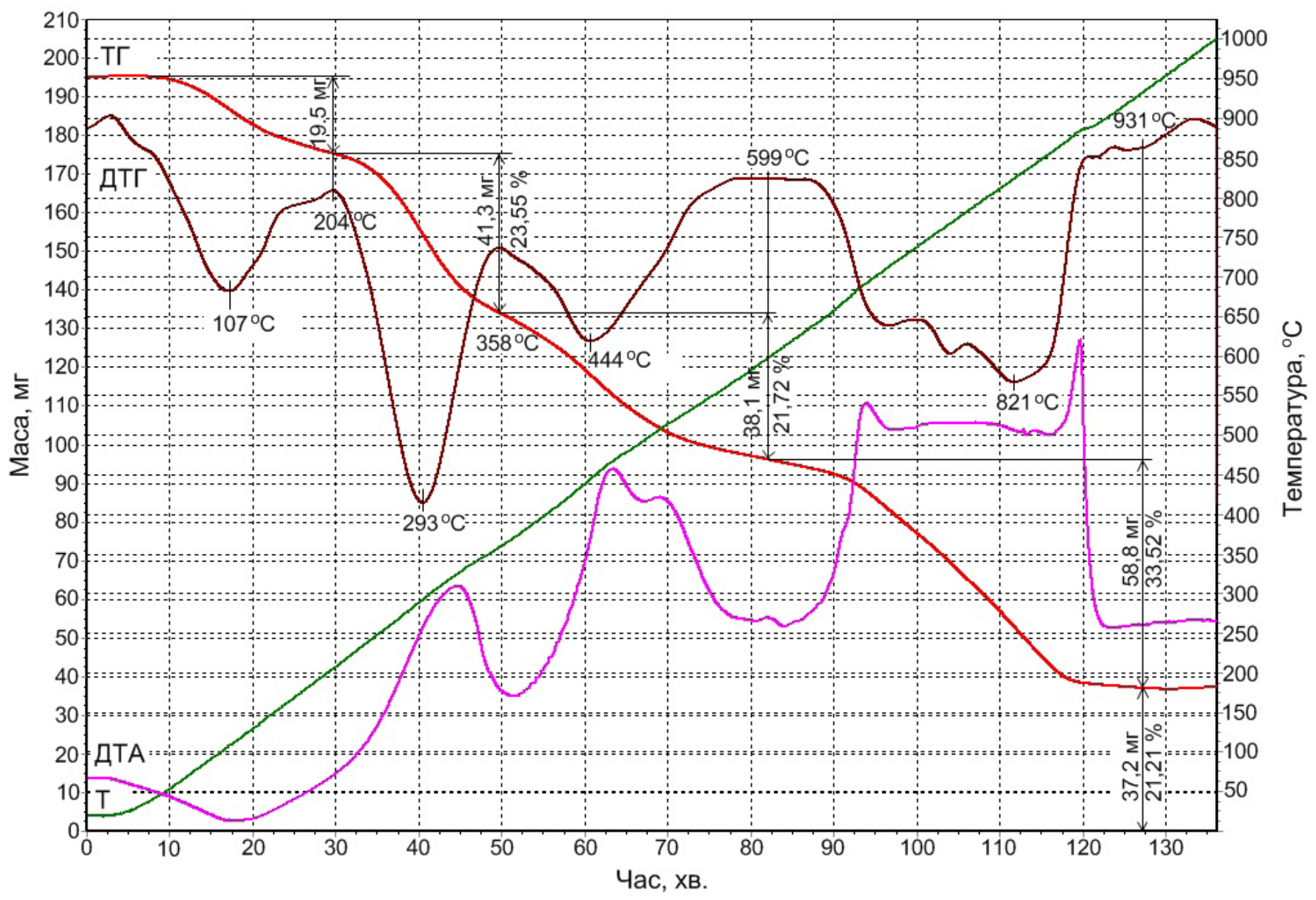

Рис. 2. Дериватограма твердого залишку фрезерного торфу після екстрагування ГР при $100{ }^{\circ}$ С протягом 60 хв. Маса зразка 194,90 мг.

Таблиця

\begin{tabular}{|c|c|c|c|c|}
\hline \multirow[b]{2}{*}{ Паливо } & \multirow[b]{2}{*}{$\begin{array}{c}\text { Вологість, } \\
\text { \% }\end{array}$} & \multicolumn{3}{|c|}{ Вміст, \% на суху масу } \\
\hline & & Органічні речовини & $\begin{array}{c}\text { Карбонати } \\
\text { (в перерахунку на } \mathrm{CaCO}_{3} \text { ) }\end{array}$ & Зола \\
\hline Торф & 29,18 & 68,28 & 4,18 & 29,73 \\
\hline $\begin{array}{l}\text { ТЗТ після екстракцції } \\
\text { при } 20{ }^{\circ} \mathrm{C}, 40 \text { хв. }\end{array}$ & 11,81 & 80,97 & 4,18 & 17,35 \\
\hline
\end{tabular}




\begin{tabular}{|l|c|c|c|c|}
\hline $\begin{array}{l}\text { ТЗТ після екстракцції } \\
\text { при } 80^{\circ} \mathrm{C}, 40 \text { хв. }\end{array}$ & 8,32 & 79,55 & 4,18 & 19,10 \\
\hline $\begin{array}{l}\text { ТЗТ після екстракцції } \\
\text { при } 100^{\circ} \mathrm{C}, 60 \text { хв. }\end{array}$ & 10,01 & 77,11 & 4,18 & 21,21 \\
\hline
\end{tabular}

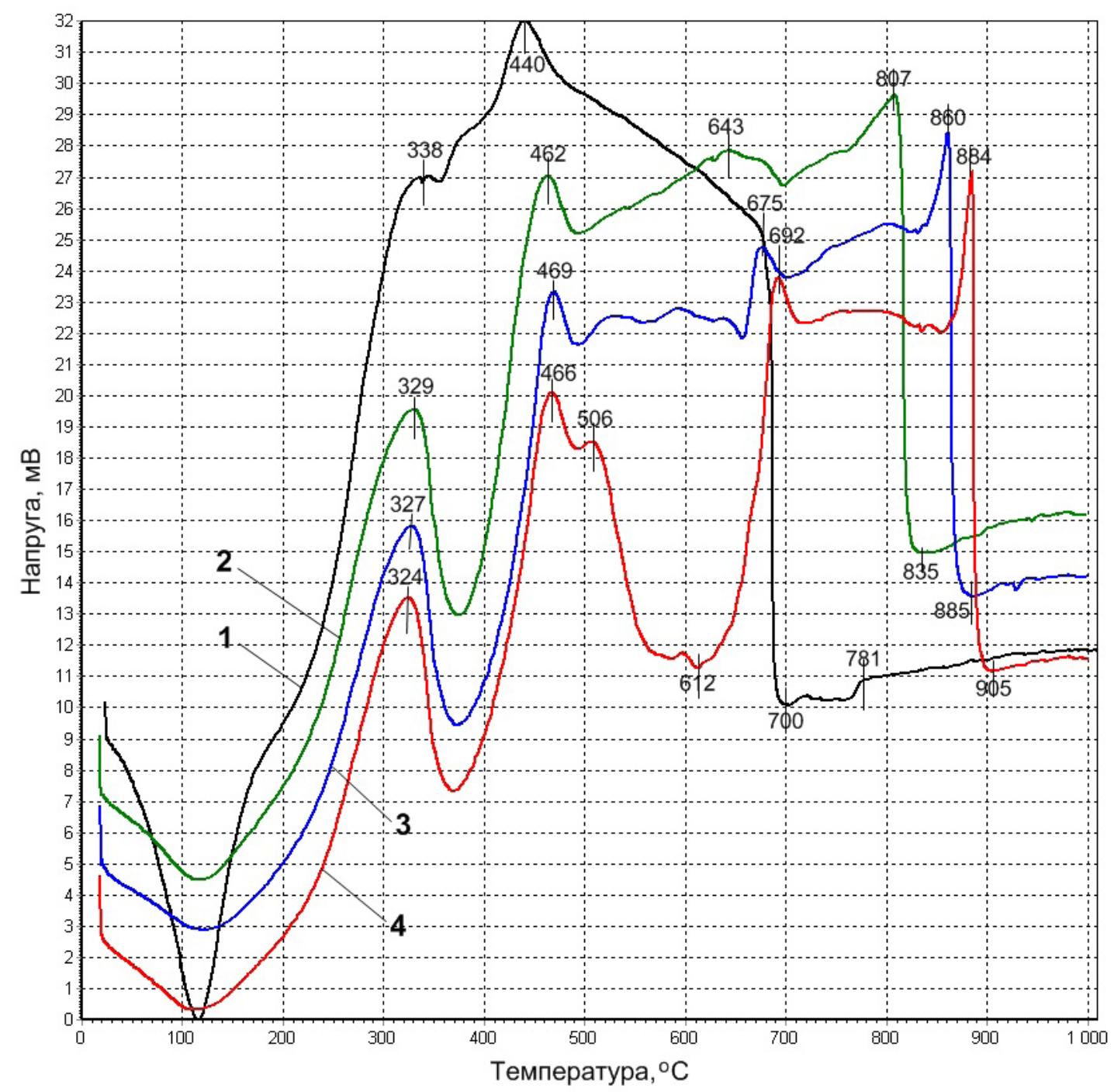

Рис. 3. Криві ДТА фрезерного торфу (1) та твердого залишку торфу після екстрагування ГР при $20^{\circ} \mathrm{C}$ протягом 40 хв. (2), $80{ }^{\circ} \mathrm{C}$ протягом 40 хв. (3) та $100^{\circ} \mathrm{C}$ протягом 60 хв. (4).

В фінальній частині екзотермічних процесів в ТЗТ спостерігається різке збільшення теплової потужності, що відображається в вигляді піків на кривих ДТА, максимуми температури яких зміщуються в область більш високих температур $\left(807 \rightarrow 860 \rightarrow 884{ }^{\circ} \mathrm{C}\right)$ при підвищенні температури екстракції (рис. 3). Як видно з кривих ДТА, різке збільшення теплової потужності властиве тільки зразкам ТЗТ. Це свідчить про ймовірність утворення нових фаз, які формуються тільки після термічної дисоціації карбонату кальцію. Розкладання карбонату кальцію в ТЗТ відбувається в тому ж температурному інтервалі, що і в чистому торфі. Відображається воно на кривих ДТА в вигляді незначного прогину (рис. 3), як наслідок накладання ендотермічного процесу термічної дисоціації карбонатів на більш потужній екзотермічний процес термічного розкладання органічних сполук. В 
зв'язку з одночасним протіканням в ТЗТ процесів термічного розкладання органічних речовин i карбонатів вміст органічних речовин (табл.) визначено шляхом корегування зміни маси зразків при умові рівності вмісту карбонатів як вихідному торфі так і в ТЗТ.

Перевірку допущення про утворення нових фаз було здійснено методом РФА. Порівняльний аналіз дифракційних даних дозволив простежити за зміною фазового складу ТЗТ, одержаних при різних температурах екстрагування ГР (рис. 4), та золи після термічного розкладання ТЗТ в печі дериватографа.

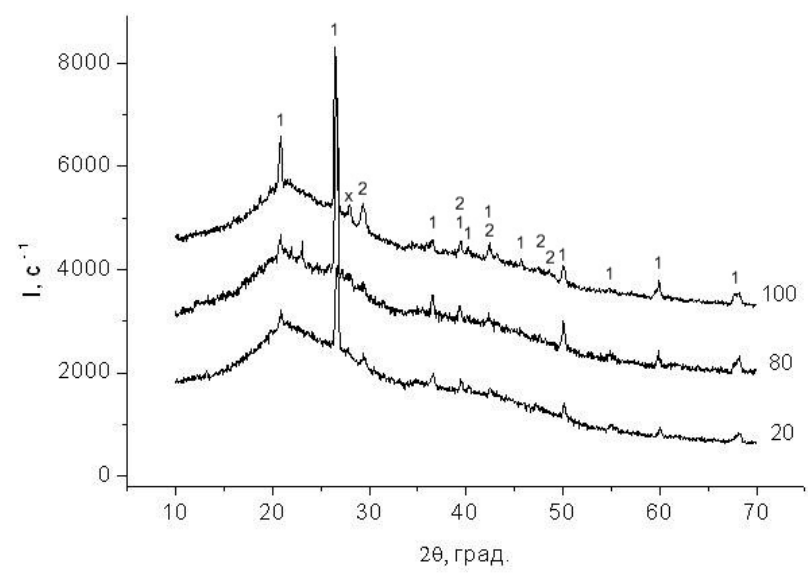

Рис. 4. Дифрактограми Т3Т, отриманого після екстракції ГР при 20, 80 ma $100{ }^{\circ} \mathrm{C}$. Позначення: 1 - $\mathrm{SiO}_{2}$; 2 - $\mathrm{CaCO}_{3}$; $\boldsymbol{x}$-неідентифікована фаза.

На дифрактограмах зразків ТЗТ (рис. 4) на фоні двох дифузних гало 3 максимумами в області $2 \theta=20 \ldots 25$ та $35 \ldots 45$ град., відповідних аморфній складовій зразка, спостерігаються дифракційні піки. Міжплощинні відстані, що їм відповідають, дозволяють віднести частину 3 них до кристалічної фази кварцу ( $\left.\mathrm{SiO}_{2}\right)$ (JCPDS картка № 85-1054) та кальциту $\left(\mathrm{CaCO}_{3}\right)$ (JCPDS картка № 83-578). Серед кристалічних фаз кварц $\epsilon$ переважаючою фазою, що видно 3 високого рівня інтенсивності його піків. Декілька піків не віднесені до певної фази. Зі збільшенням температури екстракції з 20 до $100{ }^{\circ} \mathrm{C}$ спостерігається зростання частки кристалічних речовин.

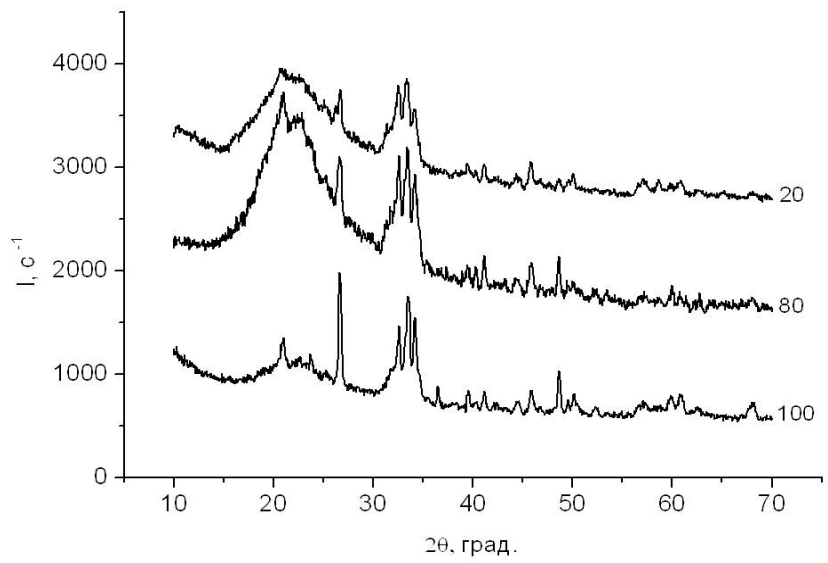

Рис. 5. Дифрактограми золи ТЗТ, отриманих після екстракції ГР при 20, 80 ma $100{ }^{\circ} \mathrm{C}$.

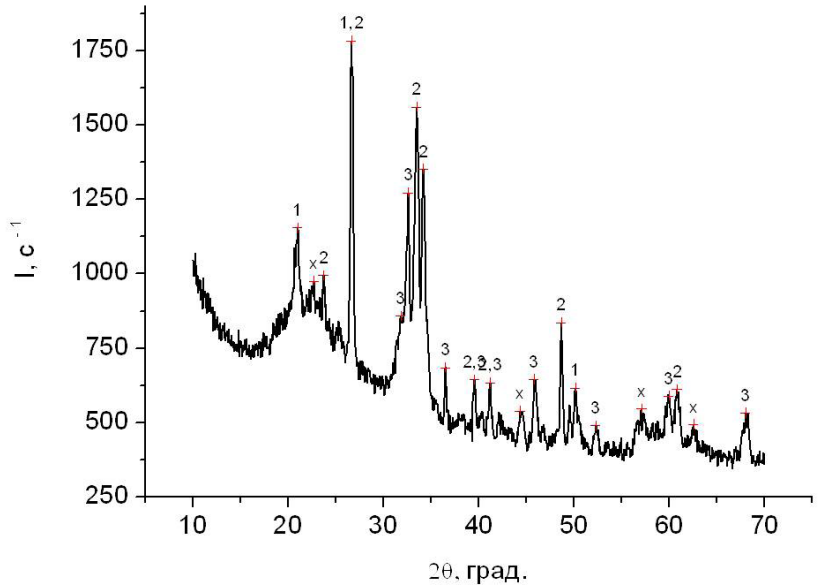

Рис. 6. Дифрактограма золи ТЗТ, отриманого після екстракції ГР при $100{ }^{\circ} \mathrm{C}$. Позначення:

$1-\mathrm{SiO}_{2} ; 2-\mathrm{Na}_{2} \mathrm{CaSi}_{3} \mathrm{O}_{8} ; 3-\mathrm{Ca}_{2} \mathrm{SiO}_{4}$; $x$-неідентифікована фаза.

На дифрактограмах зразків золи, одержаної в результаті нагрівання ТЗТ в печі дериватографа, крім піків кварцу, спостерігаються відбиття 3 високим рівнем інтенсивності, які можна віднести до силікатів складу $\mathrm{Na}_{2} \mathrm{CaSi}_{3} \mathrm{O}_{8}$ i $\mathrm{Ca}_{2} \mathrm{SiO}_{4}$ (рис. 5). Тобто, при нагріванні ТЗТ до 1000 ${ }^{\circ} \mathrm{C}$ відбувається утворення, як міні-мум, двох силікатів: $\mathrm{Na}_{2} \mathrm{CaSi}_{3} \mathrm{O}_{8}$ та $\mathrm{Ca}_{2} \mathrm{SiO}_{4}$. Зі збільшенням температури екстракції ГР до $100^{\circ} \mathrm{C}$ співвідношення силікатів збільшується убік $\mathrm{Na}_{2} \mathrm{CaSi}_{3} \mathrm{O}_{8}$. Частина кварцу не вступає в реакції і залишається вільним. Розшифровка дифрактограм виконана на прикладі зразка золи, отриманої з ТЗТ після екстракції ГР при $100{ }^{\circ} \mathrm{C}$, та приведена на рис. 6. В золі, одержаній після нагрівання зразків ТЗТ до 
$1000{ }^{\circ} \mathrm{C}$, значно менший вміст кварцу і відсутнє відбиття кальциту, який в процесі термічної дисоціації перетворюється на $\mathrm{CaO}$ та $\mathrm{CO}_{2}$. Замість оксиду кальцію та кварцу в тій же кількості утворюється нові кристалічні фази. Можна припустити, що в умовах лужного середовища, яке зберігається в залишку після обробки торфу $\mathrm{NaOH}$, при високій температурі відбуваються реакції за участю $\mathrm{CaO}, \mathrm{SiO}_{2}$ та $\mathrm{Na}+3$ утворенням нових фаз, що протікають екзотермічно. Реакції в карбонат-силікатних системах у присутності лужних сполук досить докладно досліджені при високому вмісті $\mathrm{SiO}_{2}$ у шихті при виробництві скла. Показано можливість утворення силікатів кальцію при температурах нижче 1000 $\mathrm{C}$ [14].

Утворення нових фаз може бути небезпечним при спалюванні лужного ТЗТ, одержаного з торфу з високим вмістом карбонату кальцію та кварцу, в топках теплогенераторів 3 колосниковими решітками через спікання золи.

Використовуючи криві ДТА, по методиці наведеній в [13] визначені умовні теплові ефекти екзотермічних процесів розкладання органічних речовин палив, та розраховані величини умовних питомих теплових ефектів (рис. 7).

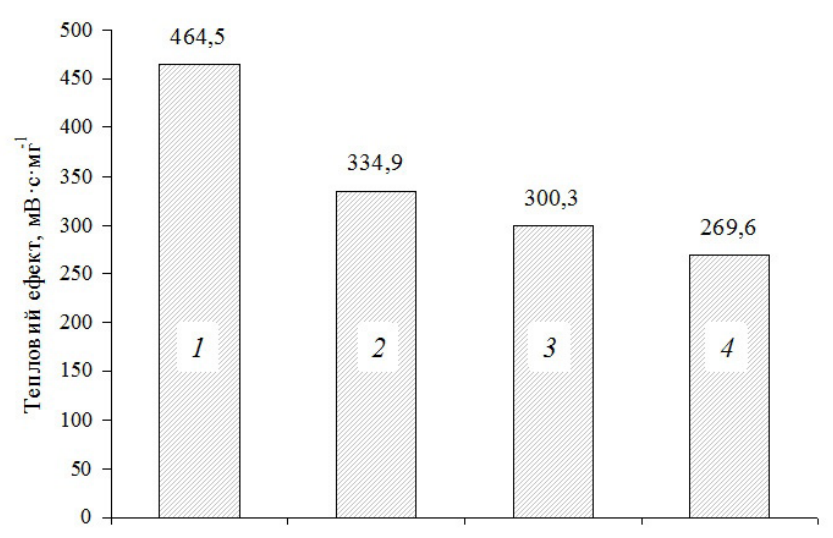

Рис. 7. Порівняння умовних питомих теплових ефектів термічного розкладання органічних речовин торфу (1) та ТЗТ після екстрагування гумусових речовин при $20^{\circ} \mathrm{C}$ протягом 40 хв. (2), при $80^{\circ} \mathrm{C}$ протягом 40 хв. (3) та при $100^{\circ}$ С протягом 60 хв. (4).

3 рисунка видно, що теплові ефекти термічного розкладання ТЗТ нижчі за тепловий ефект розкла-дання фрезерного торфу і залежать від температури екстракції. Залежність теплово- го ефекту термічного розкладання від температури екстрагування корелює 3 виходом розчинних солей гумусових кислот. При підвищенні температури екстракції з 20 до $100{ }^{\circ} \mathrm{C}$ вихід органічних речовин в екстракт збільшується. Чим менше залишається в ТЗТ органічних речовин після екстракції солей гумусових кислот 3 торфу (табл.), тим меншим $є$ тепловий ефект термічної деструкції. Одержані значення теплових ефектів лежать за межами припустимої похибки визначення теплових ефектів в дериватографі.

На наш погляд, зсув температури останнього екзотермічного піку на кривих ДТА в сторону високих температур зі збільшенням температури екстрагування можна пояснити різним складом ТЗТ, що може привести до зміни швидкості і характеру взаємодії компонентів ТЗТ при високих температурах (в лужному середовищі) та відмінностей у фазовому складі золи.

Ймовірність спікання золи при спалюванні ТЗТ 3 високим вмістом карбонатів та кварцу i зниження теплового ефекту розкладання ТЗТ в порівнянні з чистим торфом змушує розглядати ТЗТ як добавку до основного палива. Дериватографічні дослідження сумішей торфу 3 ТЗТ показали, що такий підхід є раціональним. В торф'яних сумішах з вмістом ТЗТ 10, 30 та $50 \%$ утворення нових фаз не зареєстровано (рис. 8). Внаслідок зменшення загальної лужності суміші температурний інтервал розкладання органічних речовин звужується 3551 до $514{ }^{\circ} \mathrm{C}$, а температура завершення розкладання зменшується з $750{ }^{\circ} \mathrm{C}$ при $50 \%$ ТТЗ до $708{ }^{\circ} \mathrm{C}$ при $10 \% \mathrm{~T} 3 \mathrm{~T}$.

\section{Висновки}

Термічний аналіз фрезерного торфу та твердого залишку торфу після екстрагування гумусових речовин показав, що термічне розкладання залишку проходить в більш широкому температурному інтервалі, величина якого прямо залежить від температури екстракції.

По вмісту органічних речовин у фрезерному торфі та твердому залишку торфу можна стверджувати, що вихід солей гумусових кислот мало залежить від температури екстракції.

Термічний та рентгенофазовий аналізи показали, що в процесі нагрівання екстракційного твердого залишку торфу в інтервалі 
$800 \ldots 900{ }^{\circ} \mathrm{C}$ утворюються кристалічні фази, як результат взаємодії в лужному середовищі оксиду кальцію, кварцу та іону натрію.

Утворення нових кристалічних фаз може бути небезпечним при спалюванні лужного екстракційного твердого залишку 3 високим вмістом карбонату кальцію та кварцу в топках теплогенераторів 3 колосниковими решітками через шлакування (спікання) золи.

В зв'язку 3 переходом у розчин частини органічних речовин торфу при обробці його лугом умовний питомий тепловий ефект термічного розкладання твердого екстракційного залиш- ку торфу менше за тепловий ефект розкладання торфу.

Використання твердого екстракційного залишку торфу як палива потребує підвищення його теплотворної здатності та зниження небезпеки утворення нових фаз шляхом виготовлення композиційних палив 3 додаванням чистого торфу, або деревини, твердих побутових і промислових відходів та інших палив 3 вищою теплотворною здатністю та низькою зольністю. На торфобрикетному заводі ця проблема може бути вирішена дозуванням екстракційного залишку торфу в основний технологічний потік.

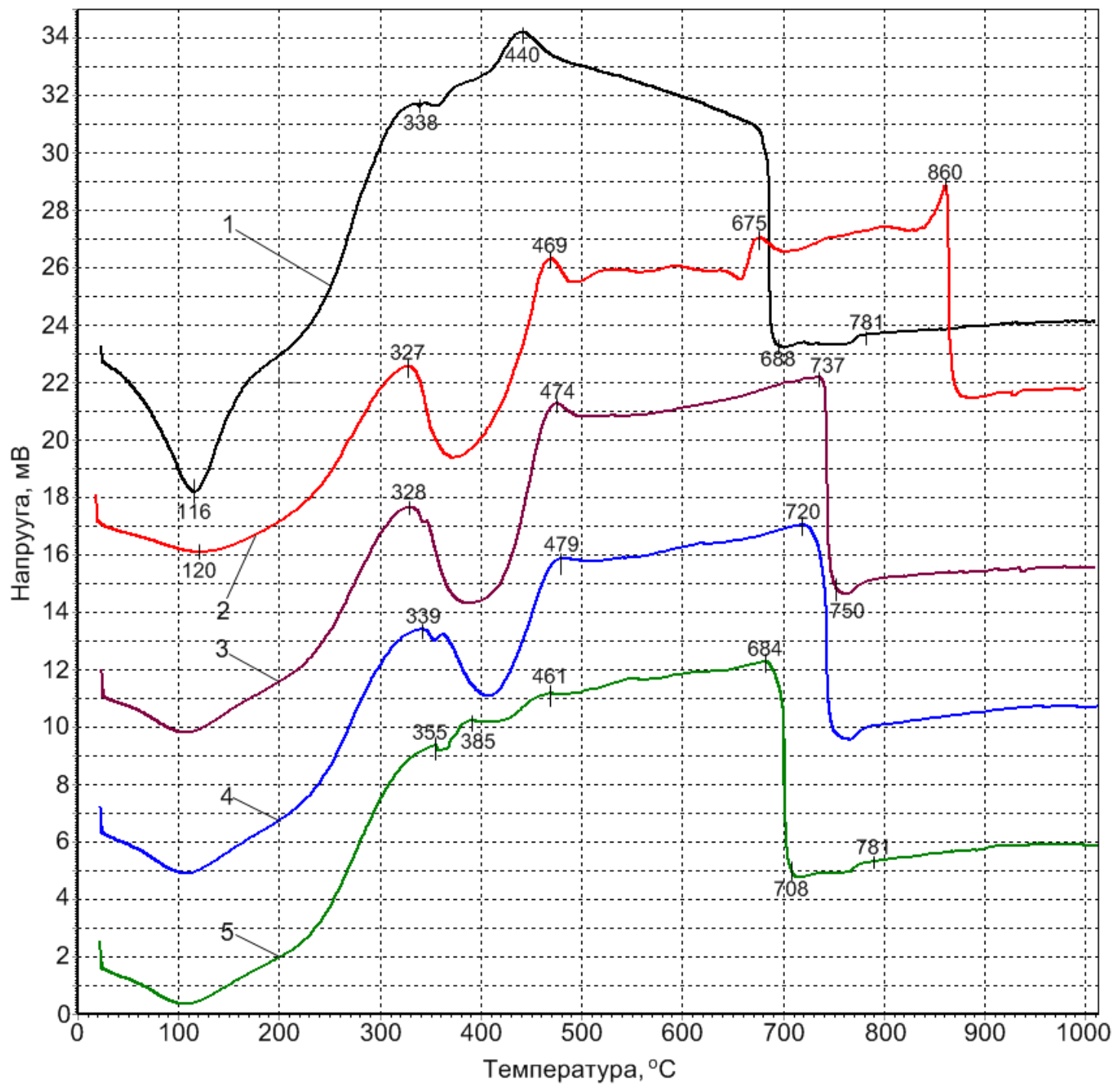

Рис. 8. Криві ДТА торфу (1), ТЗТ після екстрагування гумусових речовин при $80{ }^{\circ} \mathrm{C}$ (2), сумішей торфу з ТЗТ в кількості 50 (3), 30 (4) та 10 \% (5) до маси суміші. 


\section{ЛІТЕРАТУРА}

1. Горовая А.И., Орлов Д.С., Щербенко О.В. Гуминовые вещества. - Киев: Наукова думка, 1995. - 304 c.

2. Гуминовые вещества в биосфере / Под ред. Д.С. Орлова. М.: Наука, 1993. - 238 с.

3. Гуминовые удобрения. Теория и практика их применения / Отв. ред. В.П. Попов. - Киев: Государственное издательство сельскохозяйственной литературы, 1962. - 649c.

4. Перминова И. В. Гуминовые вещества - вызов химикам XXI века // Химия и жизнь. -2008. - №1, - С. $51-55$.

5. Чайка О.І., Гоженко Л.П., Іваницький Г.К., Корінчук Д.М. Інтенсифікація процесу диспергування низинного торфу із застосуванням пульсаційного диспергатора // Промышленная теплотехника 2013, т. 35, № 5. - С. 22 - 28.

6. Дериватограф системы Паулик Ф., Паулик Й., Эрдеи Л. Теоретические основы. Венгерский оптический завод. - Будапешт. - 1974. - 146 с.

7. Рабинович В.А., Хавин 3.Я. Краткий химический справочник. Издание 2-е, исправленное и дополненное. Под общей редакцией канд. хим. наук В.А.Рабиновича. - Изд-во «Химия», Ленинградское отделение, 1978. - 392 с.

8. Михайлик В.А., Снєжкин Ю.Ф., Белинский B.T. Применение дериватогафа для исследования влияния предварительной термической обработки на кинетику сушки растительного сырья. Тезисы IV Международной конференции «Проблемы промышленной теплотехники». 26-30 сентября 2005г. Киев, Украина. - С. 349 - 350.
9. Глущзенко И.М. Термический анализ твердых топлив. - М.: "Металлургия", 1968. - 192 с.

10. Топор Н.Д., Огородникова Л.П., Мельчакова Л.В. Термический анализ минералов и неорганических соединений. - М.: Изд-во МГУ, 1987. $-190 \mathrm{c}$.

11. Бойко E.A. Комплексный термический анализ твердых органических топлив: Монография (2-е издание, переработанное и дополненное). Красноярск: Красноярский государственный технический университет. - 2006. - 407 с.

11. Михайлик В.А., Снєжкин Ю.Ф., Белинский B.T. Применение дериватогафа для исследования влияния предварительной термической обработки на кинетику сушки растительного сырья. Тезисы IV Международной конференции «Проблемы промышленной теплотехники». 2630 сентября 2005г. Киев, Украина. - С. 349 - 350.

12. Горелик С.С., Скаков Ю.А., Расторгуев Л.Н. Рентгенографический и электронно-оптический анализ. Учебное пособие для вузов, 4-е издание. - М.: Изд-во Национального исследовательского технологического университета „МИСиС“, 2002. - 359 с.

13. Михайлик В.А., Снєжкін Ю.Ф., Корінчук Д.М. Термічне розкладання гранул палива на основі торфу та деревини // Промышленная теплотехника, - 2014. - Т. 36, - № 2. - С. 13 - 21.

14. Превращения в карбонат-силикатных системах. [Электронный ресурс] Мастерская Своего Дела [сайт]. Режим доступа: http://msd.com. ua/obzhig-cementnogo-klinkera/prevrashheniya-vkarbonat-silikatnyx-sistemax/. 


\section{STUDY OF THE THERMAL PROPERTIES OF SOLID RESIDUES OF MILLED PEAT AFTER THE HUMUS SUBSTANCES EXTRACTION}

\author{
Mykhailyk V.A. ${ }^{1}$, Snezhkin Yu.F. ${ }^{1}$, \\ Oranska O.I. ${ }^{2}$, Korinchevska T.V. ${ }^{1}$, \\ Korinchuk D.M. ${ }^{1}$
}

${ }^{1}$ Institute of Engineering Thermophysics of National Academy of Sciences of Ukraine, 2a Zhelyabova Str., Kyiv, 03680, Ukraine

${ }^{2}$ Chuiko Institute of Surface Chemistry of National Academy of Sciences of Ukraine, 17 General Naumov Str., Kyiv, 03164, Ukraine

The present research was aimed at evaluation of the thermal properties of solid alkaline residue of milled peat after extraction of humus substances to determine conformity with its requirements fuels. The thermal gravimetric and differential thermal analysis (TGA\&DTA) and X-ray diffraction were used for these purposes. It was shown that the temperature ranges of thermal decomposition of organic substances in the residue considerably wider than those of the peat, and there values are directly depend on the extraction temperature. It was found that at high temperature in the presence of calcium oxide, silicon dioxide, and sodium ions in the residue the solid phases with the following composition $\mathrm{Na}_{2} \mathrm{CaSi}_{3} \mathrm{O}_{8}$ and $\mathrm{Ca}_{2} \mathrm{SiO}_{4}$ were appeared. These new solid substances can scarify ash during combustion in the furnaces with fire-grate. The thermal effects during the thermal decomposition of organic matter and peat residue were compared. It was demonstrated that conventional specific heat effect of the thermal decomposition of the residue is less than the thermal effect of the original peat. These residues may be used as a component of composite fuel with a high calorific value and low ash content. The method of using the residue as fuel for peat briquette factories was proposed.

\section{References 14, table 1, fig. 8.}

Key words: thermal gravimetric and differential thermal analysis (TGA\&DTA), X-ray analysis, peat, humus substances, thermal decomposition.
1. Gorovaja A.I., Orlov D.S., Shherbenko O.V. Humic substances. - Kiev: Naukova dumka, 1995. -304 p. (Rus.).

2. Humic substances in the biosphere / Pod redakciej D.S. Orlova. - Moskva: Nauka, 1993. 238 p. (Rus.).

3. Humic fertilizers. Theory and practice of their application / Otvetstvennyj redaktor V.P. Popov. - Kiev: Gosudarstvennoe izda-telstvo selskohozjajstvennoj literatury, 1962. - 649 p. (Rus.).

4. Perminova I.V. Humic substances - a challenge to chemists of the XXI century // Khimia i zhizn.2008. - №1, - P. 51 - 55. (Rus.).

5. Chaika A.I., Horenko L.P., Ivanitskiy G.K., Korinchuk D.N. The intensification of the process of dispersing lowland peat using pulsating dispersant // Promyshlennaya teplotekhnika, 2013, T. 35, № 5, P. 22 - 28. (Uкr.).

6. Derivatograph systemi Paulik F., Paulik J., Erdei L. Theoretical foundations. Vengerskyi optisheskyi zavod. - Budapesht, 1974. - 146 p. (Rus.).

7. Rabinovich V.A.,Havin Z.Ia. Brief chemical directory. Izdanie 2, ispravlennoe i dopolnennoe. Pod obshei redakciey V.A. Rabinovicha. - Izdatelstvo «Khimia», Leningradskoe otdelenie, 1978. - 392 p. (Rus.).

8. Mykhailyk V.A., Snezhkin Yu.F., Belinsky V.T. Application of derivatograph to investigate the influence thermal pretreatment on the kinetics of drying plant materials. Tezisi IV Mezdunarodnoi konferencii «Problemi promishlennoi teplotechniki». 26-30 septem-ber 2005. Kiev, Ukraine. - P. 349 350. (Rus.).

9. Gluschenko I.M. Thermal analysis of solid fuels. - Moskva: «Metallurgia», 1968. - 192 p. (Rus.)

10. Topor N.D., Ogorodnikova L.P., Melchakova L.V. Thermal analysis minerals and inorganic compounds. - Moskva: Izdatelstvo MGU, 1987. 190 p. (Rus.).

11. Boyko E.A. Comprehensive thermal analysis of solid fossil fuels: Monograph (2nd edition, revised and enlarged). Krasnoiarsk: Krasnoiarskii gosudarstvennii tehnisheskii universitet, 2006. - 407 p. (Rus.)

12. Gorelik S.S., Skakov Yr. A., Rastorguev L.N. X-ray and electronoptical analysis. Ushebnoe posobie dla vuzov, 4-e izdanie. - Moskva.: Izdatelstvo 
Nacionalnogo issledovatelskogo tehnologisheskogo universiteta „MISiS“, 2002. - 359 p. (Rus.).

13. Mykhailyk V.A., Snezhkin Yu.F., Korinchuk $D . N$. Thermal decomposition of pellet fuels based on peat and wood // Promyshlennaya teplotekhnika, 2014. - T. 36, - № 2. - C. 13 - 21. (Uкr.).
14. Conversion into the carbonate-silicate systems. [Elektronniy resurs] Masterskay Svoego Dela [sayt]. Rezhim dostupa: http://msd.com.ua/ obzhig-cementnogo-klinkera/prevrashheniya-vkarbonat-silikatnyx-sistemax/.

Получено 03.03.2015 Received 03.03.2015 